\title{
Humik asit ve azotlu gübre uygulamalarının lavanta (Lavandula angustifolia Mill.) bitkisinin bazı verim ve kalite özelliklerine etkisi
}

The effect of humic acid and nitrogen fertilizer applications on some yield and quality features of lavender (Lavandula angustifolia Mill.)

\author{
Sabri ASLAN ${ }^{1}$ iD, Ercüment Osman SARIHAN ${ }^{1 \mathscr{O}}$ iD \\ ${ }^{1}$ Usak University, Faculty of Agriculture, Department of Field Crops, Uşak, Turkey.
}

MAKALE BILGISI / ARTICLE INFO

Makale tarihçesi / Article history:

DOI: $10.37908 /$ mkutbd.783161

Geliş tarihi /Received:20.08.2020

Kabul tarihi/Accepted:19.09.2020

\section{Keywords:}

Lavender, leonardite, organic matter, essential oil, fertilizer.

\footnotetext{
Corresponding author: E. O. SARIHAN

$\triangle$ : ercument.sarihan@usak.edu.tr
}

\author{
ÖZET / A B STR A C T
}

\begin{abstract}
Aims: This study was carried out to determine the effects of humic acid and nitrogen fertilizer applications on some yield and quality properties of lavender (L. angustifolia Mill.).

Methods and Results: The study was established and conducted in the Research and Application Areas of the Agriculture Faculty, Uşak University in 2019-2020. Humic acid was applied $\left(100 \mathrm{~kg} \mathrm{da}^{-1}\right)$ and not applied (Control). Two separate plots were fertilized with 3 different doses of nitrogen (Control, $30 \mathrm{~kg} \mathrm{ha}^{-1}, 60 \mathrm{~kg} \mathrm{ha}^{-1}$ ). The study was established splitplot randomized complete block design with two factors and three replications. Humic acid applications were attained in the main plots and nitrogen doses in the sub plots. In the trial; plant height $(\mathrm{cm})$, fresh herbage yield $\left(\mathrm{kg} \mathrm{ha}^{-1}\right)$, drug herbage yield $\left(\mathrm{kg} \mathrm{ha}^{-1}\right)$, drug flower yield $(\mathrm{kg}$ $\left.h a^{-1}\right)$, essential oil ratio (\%), essential oil yield $\left(\mathrm{L} \mathrm{ha}^{-1}\right)$ the number of flower heads (numbers parcel ${ }^{-1}$ ) and the length of the flower spike $(\mathrm{cm})$ were measured.

Conclusions: According to the results obtained; $1^{\text {st }}$ year in trial; the drug flower yield was $343 \mathrm{~kg} \mathrm{ha}^{-1}$ in the plots treated with humic acid, while it was $274 \mathrm{~kg} \mathrm{ha}^{-1}$ in the plots without humic acid. In the $2^{\text {nd }}$ year, these values were determined as $3100 \mathrm{~kg} \mathrm{ha}^{-1}$ and $1426 \mathrm{~kg} \mathrm{ha}^{-1}$, respectively. Essential oil yield was $27.7 \mathrm{~L} \mathrm{ha}^{-1}$ in the first year in the plots where humic acid was applied, while it was $123 \mathrm{~L} \mathrm{ha}^{-1}$ in the second year. However, these values were 21.4 and $55.1 \mathrm{~L} \mathrm{ha}^{-1}$ in the $1^{\text {st }}$ and $2^{\text {nd }}$ years, respectively, in the plots where humic acid was not applied.

Significance and Impact of the Study: As a result, it has been determined that humic acid application has a positive contribution to the development of lavender plants and the application amount of nitrogen fertilization is suitable among 30-60 $\mathrm{kg} \mathrm{ha}^{-1}$.
\end{abstract}

Atıf / Citation: Aslan S, Sarıhan EO (2021) Humik asit ve azotlu gübre uygulamalarının lavanta (Lavandula angustifolia Mill.) bitkisinin bazı verim ve kalite özelliklerine etkisi. MKU. Tar. Bil. Derg. 26(1) : 29-40. DOI: 10.37908/mkutbd.783161

\section{Giriş}

Canlı ve cansız birçok maddeden oluşan toprağın, canlıların beslenmesinde çok önemli bir yeri vardır. Toprakta yer alan canlılar ile bu maddeler arasında çok sıkı bir ilişkisi söz konusudur. Bu canlılar çeşitli yollarla toprağa gelmiş, farklı organik maddelerin değişimini gerçekleştirirler. Toprakta bu organik maddelerin ilk olarak parçalanması, sonrasında ayrışması ve hümifikasyonu gerçekleşir (Altınbaş ve ark., 2004; Akıncı 2011). Parçalanma ve ayrışma neticesinde toprakta humikli maddeler oluşurlar. Oluşan bu maddelerin en 
önemlilerinden birisi ise humik asittir. Bu maddeler toprağın fiziksel özelliklerini iyileştirip, işlenebilmesini kolaylaştırırlar. Killi, balçık veya sıkışmış toprakları çok daha yumuşak bir hale sokarak, daha geçirgen bir yapıda olmasını sağlarlar. Toprağın havalanması ve su tutmasını arttırarak, tohumların çimlenmesini olumlu yönde etkilerler ve toprağın mikroflorasını geliştirirler (Ay, 2015). Yüksek miktarda humik asit içeren humatlar uzun süreli ve iyi bir humus kaynağıdırlar. Yüksek miktardaki fulvatlı ve humatlı humik asit içeren maddelerden birisi olan leonardit de bu yüzden önemli bir humik asit kaynağıdır (İstanbulluoğlu, 2012). Linyitin kömürleşmesi sırasında yüksek oranda oksidasyona uğrayarak oluşan bir madde olan leonardit, içerisinde \%35-85 arasında değişen miktarlarda humik asit bulundurabilmektedir (Avşaroğlu, 2019). Leonardit içerisindeki düşük molekül ağırlıklı humikli maddeler (fulvat) bitkilerdeki metabolik olayları etkileyerek, kimyasal reaksiyonlarda yer alan maddelerin oluşumunda yer alırken, yüksek molekül ağıllıklarına sahip humikli maddeler (humat) toprağın fiziksel yapısını etkilemektedirler. Leonardit, içerisinde humik asitler haricinde; makro ve mikro besin elementleri içeren, kömür düzeyine ulaşamamış tamamen doğal, organik maddeler de söz konusudur. Bu maddeler içerdiği yüksek orandaki humik asitlerden dolayı ekonomik değere sahiptirler (İstanbulluoğlu, 2012).

Kimyasal gübrelerin tarımda her geçen gün artan miktarlarda kullanımı, humusun topraktaki miktarını hızlı bir şekilde azaltmaktadır. Bu sorunu gidermek için günümüzde tarımsal uygulamalarda humik asit kullanımı yaygınlaşmaya başlanmıştır. Humik asitler toprağın fiziksel, kimyasal, biyolojik özeliğini iyi yönde geliştirirler. Toprağın hava ve su geçirimini arttırmakta, hatta ağırlığının 20 katı kadar su tutabilmesini sağlamaktadır (Engin ve ark., 2012). Topraktaki makro ve mikro bitki besinlerinin (potasyum, fosfor, azot, demir ve çinko gibi) bitkiler tarafından emilimini kolaylaştırarak, bitkilerin kök gelişimini arttırıp bitkilerin gelişmesine olumlu katkı sağlarlar. Humikli maddeler; fulvik, humik ve humin olarak üç ana grupta toplanmaktadır. Humik asitlerin uygulaması bitkiye veya tohuma, yapılabileceği gibi doğrudan toprağa da yapılabilmektedir. Ticari şekilde toz halinde veya sıvı halde satışa sunulan formları söz konusudur. Türkiye'de humik asit içeren maddelerle; bitki verimine, toprağın organik madde ve humikli madde içeriğine etkilerinin değerlendirildiği, çeşitli çalışmalar devam etmektedir (Engin ve ark., 2012).

Humik asit uygulamaları toprak yapısını iyileştirmek, bitki kök sistemlerinin gelişmesine katkı sağlamak amacıyla günümüzde tarımsal alanda giderek artmaktadır. Özellikle kültür bitkilerinde giderek yaygınlaşan kullanımlarda verim ve kalite açısından artışların olduğu görülmektedir. Tıbbi ve aromatik bitkilerin yetiştiriciliğinde; verim yanında kalitenin de çok daha ön plana çıktığı görülmektedir. Lavanta bitkisinin yetiştiriciliğinde elde edilen uçucu yağ verimi ve kalitesinin arttırımasında humik asidin etkisinin belirlenmesi önemlidir. Bu alanda Türkiye'de daha önce yapılmış çalışmaya rastlanılmamıştır. Türkiye'de son yıllarda tarımı giderek artış gösteren lavanta bitkisinin yetiştiriciliğine yönelik çalışmalara hız verilmelidir. Bozkıran ve Giray (2014), günümüzde en çok İstanbul, İzmir, Konya, Denizli, Hatay ve Bursa illerinde lavanta yağının ticaretinin yapıldığını bildirmişlerdir. Ticari değeri de artış gösteren bu ürünün yetiştiriciliğine yönelik çalışmalar önem arz etmektedir. Bu açıdan yapılan bu çalışma literatürdeki bir bilginin tamamlanmasına önemli katkı sağlamaktadır. Son yıllarda tarımsal desteklemelerle tıbbi ve aromatik bitkilerin yetiştiriciliğinin de geliştirilmesine çalışılmaktadır. Ayrıca bu çalışma, Uşak ilinde lavanta tarımının gelişimine de katkı sunabilecek niteliktedir. Bölgede, geleneksel olarak yetiştirilmekte olan haşhaş haricinde, tıbbi özelliği bulunan bitkilerin yetiştiriciliği oldukça sınırlıdır. Uşak ili, iklim bakımından Ege bölgesi ve İç Anadolu Bölgesi arasında kalan bir bölgede yani geçit kuşağında yer almaktadır. II genelinde; tarla tarımı olarak çoğunlukla kuru tarım sistemi uygulanmaktadır. Tahıllar (arpa, buğday, yulaf, çavdar vb.) başta olmak üzere bazı endüstri bitkileri ve yem bitkilerinin yetiştiriciliği bu kapsamda yapılmaktadır.

Bu çalışma; humik asit uygulamaları ile farklı dozlarda azotlu gübrelemenin lavanta bitkisinin bazı verim ve kalite özelliklerinin üzerine olan etkilerini belirlemek amacıyla yapılmıştır.

\section{MATERYAL ve YÖNTEM}

Bu çalışma Uşak Üniversitesi Ziraat ve Doğa Bilimleri Fakültesi Araştırma ve Uygulama Alanında yürütülmüştür. Ekim 2018 yılında araziye dikimleri gerçekleştirilen lavanta bitkilerinin, 2019 ve 2020 yetiştirme yılında bazı bitkisel ve tarımsal özellikleri üzerinde ölçümler gerçekleştirilmiştir. Denemede materyal olarak lavanta (Lavandula angustifolia Mill.) bitkileri kullanılmıştır. Denemede köklendirilerek, saksılarda yetiştirilmiş 1-2 yaşındaki lavanta bitkileri kullanılmıştır. Bu bitkiler 4'er $\mathrm{m}^{2 \prime}$ lik deneme parsellerine $100 \mathrm{~cm}$ sıra arası ve $50 \mathrm{~cm}$ sıra üzeri dikim mesafesi verilerek dikilmişlerdir. Denemede toprak analizleri; humik asit ve azotlu gübre uygulamaları yapılmadan önce ve deneme sonuçları alındıktan sonra olmak üzere iki ayrı dönemde alınan toprak numuneleri üzerinde 
yapılmıştır. Humik asit uygulanan ve uygulanmayan parsellerden ayrı ayrı olmak üzere $0-30 \mathrm{~cm}$ derinlikten alınan toprak numuneleri üzerinde yapılan toprak analizleri Uşak Tarım il Müdürlüğü toprak analiz laboratuvarında yaptırılmıştır. Analizlerde toprağın yapısı, pH'sı, tuzluluk oranı, kireç içeriği, organik madde içeriği ve temel besin maddeleri azot $(\mathrm{N})$, fosfor $\left(\mathrm{P}_{2} \mathrm{O}_{5}\right)$ ve potasyum $\left(\mathrm{K}_{2} \mathrm{O}\right)$ içeriği belirlenmiştir.

Denemede iki yıl süreyle humik asit uygulaması, humik asit uygulanmış (100 $\left.\mathrm{kg} \mathrm{ha}^{-1}\right)$ ve uygulanmamış (Kontrol) parsellere iki ayrı şekilde yapılmıştır. Bu parsellerin içerisinde de 3 farklı dozda azot (Kontrol, 30, $60 \mathrm{~kg} \mathrm{~N}$ ha $\left.{ }^{1}\right)$ uygulanan parseller oluşturulmuştur. Denemede $\% 40^{\prime}$ Iık humik asit içeren ticari olarak satılan toz halindeki humik asit kullanılmıştır. Toz halindeki humik asit su içerisinde eritilerek parsellere bitkilerin dikimi esnasında verilmiştir. Ayrıca \%33'lük amonyum nitrat gübresinden hazırlanan farklı dozlardaki azotlu gübreler uygulanmıştır. Denemede toplam 18 adet parsele, her parsele 8'er adet bitki olacak şekilde, toplamda 144 adet bitkinin dikimleri gerçekleştirilmiştir.

Denemede; bitki boyu $(\mathrm{cm})$, taze herba verimi $\left(\mathrm{kg} \mathrm{ha}^{-1}\right)$, drog herba verimi $\left(\mathrm{kg} \mathrm{ha}^{-1}\right)$, drog çiçek verimi $\left(\mathrm{kg} \mathrm{ha}^{-1}\right)$, uçucu yağ oranı (\%), uçucu yağ verimi $\left(\mathrm{kg} \mathrm{ha}^{-1}\right)$, çiçek başağı sayısı (adet parsel ${ }^{-1}$ ), çiçek başağı boyu $(\mathrm{cm})$, karakterlerinde ölçümler yapılmıştır. Denemede uçucu yağ oranları(\%) clavenger aparat kullanılarak 100'er gr kuru drog çiçek materyali kullanılarak belirlenmiştir. Denemede hasatlar tam çiçeklenme döneminde; 1 . yıl 20
Temmuz 2019'da, 2. yıl 16 Temmuz 2020'de yapılmıştır (Şekil 1 ve Şekli 2).

Deneme tesadüf bloklarında bölünmüş parseller deneme desenine göre 3 tekrarlamalı olarak kurulup yürütülmüştür. Ana parseller humik asit uygulamaları ve alt parsellere de azot dozları yerleştirilmiştir İncelenen karakterlere ait ortalamalar ve varyans analizleri MstatC istatistik paket programıyla yapılmış; ortalamalar arasındaki farklar ise Duncan testi ile belirlenmiştir.

\section{BULGULAR ve TARTIŞMA}

Denemede ölçümü yapılan tüm karakterlere ilişkin yıllara ait ortalama değerler arasındaki farkların istatistiki olarak önemli çıkması nedeni ile çalışmada verilen tüm tablolarda yıllar, istatistiki olarak ayrı ayrı değerlendirilmiştir. Aşağıda verilen sonuçlara ait tablolarda her karaktere ait değerlerin sunulduğu tabloların alt kısımlarında humik asit uygulamaları, azot dozu ve humik asit $x$ azot dozu interaksiyonları arasındaki istatistiki değerlendirmeleri ve analizlerin önemlilik seviyeleri ayrı ayrı belirtilmiştir.

\section{Toprak analiz sonuçları}

Denemede yapılan toprak analizlerine ait sonuçlar Tablo 1 'de sunulmuştur. Denemede humik asit uygulaması ve azotlu gübre uygulaması yapılmadan önce yapılan toprak analizinde deneme yerine ait toprağının hafif alkali, hafif tuzlu, orta kireçli killi tınlı yapıda, organik madde içeriğinin ise çok düşük seviyede olduğu belirlenmiştir.

Tablo 1. Humik asit uygulamalarına göre deneme alanındaki toprak analiz sonuçları

Table 1. Soil analysis results of the study with respect to humic acid applications)

\begin{tabular}{|c|c|c|c|c|c|c|c|c|}
\hline $\begin{array}{l}\text { Toprak örneği } \\
(0-30 \mathrm{~cm})\end{array}$ & $\mathrm{pH}$ & $\begin{array}{c}\text { Tuz } \\
\left(\text { mikroS cm }{ }^{-1}\right)\end{array}$ & $\begin{array}{c}\text { Kireç } \\
\%\end{array}$ & $\begin{array}{c}\text { Organik } \\
\text { madde } \\
(\%)\end{array}$ & Yapı & $\begin{array}{l}\text { Toplam } \\
\text { Azot (\%) }\end{array}$ & $\begin{array}{l}\text { Faydalı P } \\
\text { (ppm) }\end{array}$ & $\begin{array}{l}\text { Faydalı K } \\
\text { (ppm) }\end{array}$ \\
\hline Uygulama öncesi & $\begin{array}{c}\text { Hafif } \\
\text { alkali } \\
7.70\end{array}$ & $\begin{array}{l}\text { Hafif Tuzlu } \\
1059\end{array}$ & $\begin{array}{c}\text { Orta } \\
\text { kireçli } \\
9.1\end{array}$ & $\begin{array}{l}\text { Çok az } \\
0.084\end{array}$ & $\begin{array}{l}\text { Killi } \\
\text { tınlı }\end{array}$ & $\begin{array}{l}\text { Fakir } \\
0.042\end{array}$ & $\begin{array}{c}\text { Çok fakir } \\
0.56\end{array}$ & $\begin{array}{l}\text { Yeterli } \\
250\end{array}$ \\
\hline $\begin{array}{l}\text { Humik Asit } \\
\text { Uygulanmayan } \\
\text { Parseller }\end{array}$ & $\begin{array}{l}\text { Orta } \\
\text { alkali } \\
8.01\end{array}$ & $\begin{array}{c}\text { Tuzsuz } \\
976\end{array}$ & $\begin{array}{c}\text { Orta } \\
\text { kireçli } \\
15.0\end{array}$ & $\begin{array}{l}\text { Çok az } \\
0.56\end{array}$ & $\begin{array}{l}\text { Killi } \\
\text { tınlı }\end{array}$ & $\begin{array}{l}\text { Fakir } \\
0.028\end{array}$ & $\begin{array}{l}\text { Çok fakir } \\
0.40\end{array}$ & $\begin{array}{c}\mathrm{Az} \\
120\end{array}$ \\
\hline $\begin{array}{l}\text { Humik asit uygulanan } \\
\text { Parseller }\end{array}$ & $\begin{array}{l}\text { Orta } \\
\text { alkali } \\
8.16\end{array}$ & $\begin{array}{c}\text { Tuzsuz } \\
829\end{array}$ & $\begin{array}{c}\text { Fazla } \\
\text { kireçli } \\
22.7\end{array}$ & $\begin{array}{l}\text { Çok az } \\
0.76\end{array}$ & $\begin{array}{l}\text { Killi } \\
\text { tınlı }\end{array}$ & $\begin{array}{l}\text { Fakir } \\
0.038\end{array}$ & $\begin{array}{c}\text { Çok fakir } \\
0.64\end{array}$ & $\begin{array}{c}\text { Yeterli } \\
180\end{array}$ \\
\hline
\end{tabular}

Hasat sonrasında alınan toprak örneklerinde humik asit uygulanan ve humik asit uygulanmayan parsellerde deneme alanı topraklarının orta alkali, tuzsuz ve fazla kireçli, killi-tınlı bir yapıda toprak yapısına sahip olduğu görülmektedir. Tüm toprak analizlerinde toprağın azotça fakir olduğu görülse de dikilen bitkilerin hasat sonrası gübreleme ile verilen azotları da kullandıkları göz önüne alınmalıdır. Faydalı fosfor ve potasyum değerleri de aynı şekilde değerlendirilmelidir. Her ne kadar tüm toprak analizlerinde toprağın organik madde içeriği çok az ise de humik asit uygulamasıyla organik madde içeriğinde bir artışın olduğu da görülmektedir (Tablo 1). 


\section{Bitki boyu (cm)}

Bitki boyu, karakterine ait olarak denemede 1. ve 2 . yıllarda yapılan ölçümlerde; ilk yıl, yapılan humik asit ve azotlu gübre uygulamalarının, bitki boyu üzerine etkisi tespit edilmemiştir (Tablo 2). Bitki boyu değerleri 70.4$73.1 \mathrm{~cm}$ arasında değişmiştir. İkinci yıldaki ölçümlerde ise humik asit uygulamasının bitki boyunu olumlu yönde etkilediği belirlenmiştir. Humik asit uygulanan parsellerde bitki boyu $89.5 \mathrm{~cm}$ iken humik asit uygulanmayan parsellerde bitki boyunun $85.5 \mathrm{~cm}$ olduğu görülmüştür. Gelişmelerini sürdüren bitkilerin 2. yılda daha da büyümeleri sebebiyle boylarının ortalama olarak ilk yıldaki değerlere göre $15-16 \mathrm{~cm}$ daha uzun olduğu görülmektedir (Tablo 2) (Şekil 1 ve Şekil 2). Humik asit uygulamasının bitki boyu üzerinde 2. yıldan itibaren etkisini gösterdiği görülmektedir. Birinci yıl (tesis yılı) ile 2. yıl bitki boyu ortalama değerleri arasındaki farkın, gelişmelerini sürdüren bitkilerin büyümesiyle birlikte ortaya çıktığı görülmektedir (Tablo 2). Balyemez (2014), Harran ovası koşullarında farklı lavanta türlerinin verim ve bazı bitkisel özelliklerini belirlemek üzere yaptığı çalışmasında; $L$. angustifolia türüne ait olan İngiliz ve Grosso Tina lavanta çeşitlerinde bitki boyunun 29,30$31.15 \mathrm{~cm}$ arasında değiştiğini belirlemiştir. Arabacı ve Bayram (2005), ise bitki boyu değerlerinin 20x60 sıra arası mesafede 60.4-69.5 cm arasında değiștiğini belirtmişlerdir. Atalay (2008) lavantada, en uzun bitki boyunun $2.5 \mathrm{~kg} \mathrm{da}$ azot gübresinin uyguladığı parsellerden $(59.80 \mathrm{~cm})$, en kısa bitki boyunun ise koyun gübresi uygulanan parsellerden $(46.14 \mathrm{~cm})$ elde edildiğini vurgulamıştır. Özyazıcı ve Kevseroğlu (2019) yaptıkları çalışmada, lavantada bitki boyu değerlerinin 30.0-40.6 cm arasında değiştiğini belirtmiştir. Araştırıcıların belirledikleri ortalama bitki boyu değerlerine göre bu çalışmada daha uzun bitki boyu değerleri tespit edilmiştir. Bunun ilk nedeni parsellere dikimi yapılan bitkilerin 1-2 yaşında, biraz gelişmiş bitkiler olması ve ikinci nedeni ise denemenin kurulduğu yerlerin ekolojik koşullarının ve uygulamaların birbirlerinden farklı olmasından kaynaklanmaktadır.

Tablo 2. Bitki boyu ve taze herba verimi $\left(\mathrm{kg} \mathrm{ha}^{-1}\right)$ karakterlerine ait ortalama değerler ve farkları

Table 2. Average values and differences of plant height and fresh herb yield $\left(\mathrm{kg} \mathrm{ha}^{-1}\right)$ characters

\begin{tabular}{|c|c|c|c|c|c|c|}
\hline \multirow{2}{*}{$\begin{array}{c}\text { Ölçülen } \\
\text { Karakterler }\end{array}$} & \multirow{2}{*}{$\begin{array}{c}\text { Yetiştirme } \\
\text { Yılı }\end{array}$} & \multirow[t]{2}{*}{ Humik Asit Uygulaması } & \multicolumn{3}{|c|}{ Azot Dozu } & \multirow[b]{2}{*}{ Ortalama } \\
\hline & & & Kontrol & $30 \mathrm{~kg} \mathrm{ha}^{-1}$ & $60 \mathrm{~kg} \mathrm{ha}^{-1}$ & \\
\hline \multirow{6}{*}{$\begin{array}{l}\text { Bitki Boyu } \\
(\mathrm{cm})\end{array}$} & \multirow{3}{*}{1 yıl (2019) } & Humik Asit Uygulamasız & 70.4 & 71.4 & 70.4 & 70.7 \\
\hline & & Humik Asit Uygulamalı & 71.2 & 73.1 & 71.1 & 71.8 \\
\hline & & Ortalama & 70.8 & 72.3 & 70.8 & \\
\hline & \multirow{3}{*}{ 2.yıl (2020) } & Humik Asit Uygulamasız & 85.1 & 87.4 & 83.8 & $85.5 \mathrm{~b}$ \\
\hline & & Humik Asit Uygulamalı & 89.7 & 91.9 & 86.9 & $89.5 \mathrm{a}$ \\
\hline & & Ortalama & 87.4 & 89.7 & 85.4 & \\
\hline
\end{tabular}

Bitki boyu için: 1. yıl: humik asit uygulaması, gübre dozu ve humik asit x gübre dozu interaksiyonu: önemli değil (ÖD);

2. Yıl: Humik asit uygulaması 0,05 önemli, gübre dozu ve humik asit $x$ gübre dozu interaksiyonu: önemli değil (ÖD)

1.yll için CV: \% 3.76; 2.yıl için CV:\% 3.90.

\begin{tabular}{ccccccc}
\multirow{3}{*}{$\begin{array}{c}\text { Taze, herba } \\
\text { verimi } \\
\left(\mathrm{kg} \mathrm{ha}^{-1}\right)\end{array}$} & 1 yıl (2019) & Humik Asit uygulamasız & 1240 & 1820 & 1580 & 1550 \\
\cline { 2 - 6 } & & Humik Asit uygulamalı & 1460 & 2000 & 2070 & 1840 \\
\cline { 2 - 6 } & \multirow{2}{*}{ 2.yıl (2020) } & Ortalama & $1350 \mathrm{~B}$ & $1910 \mathrm{~A}$ & $1830 \mathrm{~A}$ & \\
\cline { 2 - 6 } & & Humik Asit Uygulamasız & 6920 & 7780 & 7570 & $7430 \mathrm{~b}$ \\
\cline { 2 - 6 } & Humik Asit Uygulamalı & 11310 & 11680 & 12250 & $11750 \mathrm{a}$ \\
\cline { 2 - 6 } & Ortalama & 912 & 973 & 991 &
\end{tabular}

Taze, herba verimi için: 1. yıl: humik asit uygulaması, humik asit x gübre dozu interaksiyonu: önemli değil (ÖD), gübre dozu: 0,01 önemli;

2. yıl ise humik asit uygulaması istatistiki olarak 0,01 önemli, gübre dozu ve humik asit x gübre dozu interaksiyonu: önemli değildir (ÖD).

1.yıl için CV: \% 9.91; 2.yıl için CV:\% 8.36 . 


\section{Taze herba verimi $\left(\mathrm{kg} \mathrm{ha}^{-1}\right)$}

Bu çalışmada ilk yıl, gübre dozlarının elde edilen taze herba verimini etkilediği görülmektedir (Tablo2). Bu sonuçlara göre en düşük verim kontrol parsellinden (1 $350 \mathrm{~kg} \mathrm{ha}^{-1}$ ) elde edilirken, en yüksek $30 \mathrm{~kg} \mathrm{ha}^{-1}$ azot dozu gübrelemesinden (1 $910 \mathrm{~kg} \mathrm{ha}^{-1}$ ) elde edilmiştir. Azot gübrelemesinin taze herba verimini arttırdığı görülmektedir. Bu artış oranı kontrol parsellerine göre her iki gübre dozunda \% 35.18-41.48 arasında değişmiştir. Humik asit uygulamasına göre durum değerlendirildiğinde; illk yıldaki sonuçlara göre, humik asit uygulamasının etkisinin önemli olmadığı görülmektedir. Ancak yine de humik uygulaması yapılan parsellerde $1840 \mathrm{~kg} \mathrm{ha}^{-1}$, humik asit uygulanmayan parsellerden ise $1550 \mathrm{~kg} \mathrm{ha}^{-1}$ verim elde edilmiştir. 2 . yıldan itibaren ise yapılan humik asit uygulamasının etkisinin önemli olduğu ve verim değerlerinin humik asit uygulanan parsellerde $11750 \mathrm{~kg} \mathrm{ha}^{-1}$ iken uygulanmayan parsellerde $7430 \mathrm{~kg} \mathrm{ha}^{-1}$ olduğu görülmüştür (Tablo 2). Çalışmanın birinci ve ikinci yılı değerleri arasındaki farkın bu denli fazla olmasının bir nedeni de ilk yılın tesis yılı olması ve bitkilerin verimlerinin daha düşük olmasıdır. Bitkiler asıl gelişmelerini ikinci yıldan itibaren daha iyi göstermektedirler. Yapılan uygulamaların da katkısıyla verim değerleri arasındaki farklar bu şekilde oluşmuştur. Buna benzer sonuçları aşağıda verilen araştırıcıların sonuçlarında da görmek mümkündür. Ceylan ve ark. (1996), İzmir-Bornova şartlarında yaptıkları çalışmalarında taze çiçek veriminin hasadın 1. yılında 789 $\mathrm{kg} \mathrm{da}^{-1}$, 2. yılında $1252 \mathrm{~kg} \mathrm{da}^{-1}$ ve 3. yılında $690 \mathrm{~kg} \mathrm{da}^{-1}$ olduğunu belirlemişlerdir. Ayrıca, taze çiçek verimi üzerine azotlu gübrenin önemli bir etkisinin olmadığını tespit etmişlerdir. Arabacı ve Bayram (2005), lavantanın taze çiçek verimi üzerine, azotlu gübrelemenin bir etkisinin olmadığını belirtmişlerdir. Yaptıkları araştırmalarında; 2002 yılında $556.7 \mathrm{~kg} \mathrm{da}^{-1}, 2004$ yılında $1499 \mathrm{~kg} \mathrm{da}^{-1}$ taze çiçek verimi saptamışlardır. Ceylan ve ark. (1990) yaptıkları bir diğer çalışmada 301.9 - 1696.8 $\mathrm{kg} \mathrm{da}^{-1}$ taze herba verimi elde etmişlerdir. Sınmaz (2001) $116-304,8 \mathrm{~kg} \mathrm{da}^{-1}$ arasında değiştiğini bildirmişlerdir. Özyazıcı ve Kevseroğlu (2019) yaptıkları çalışmalarında taze herba veriminin denemenin ilk yılında ortalama $872,2 \mathrm{~kg} \mathrm{da}^{-1}$, ikinci yılında ise $2860,6 \mathrm{~kg} \mathrm{da}^{-1}$ olduğunu tespit etmişlerdir. Bu çalışmadaki taze herba verimi sonuçları Ceylan ve ark. (1990), Ceylan ve ark. (1996) ve Arabacı ve Bayram (2005) ile uyumlu iken, Sınmaz (2001)'den daha yüksektir. Özyazıcı ve Kevseroğlu (2019)'un sonuçlarından ise düşüktür. Bu farklılıkların sebebi, araştırmalarda etkileri araştırılan uygulamaların farklı oluşu ve çalışmaların yapıldığı yerlerin iklim, toprak, rakım, yön ve yöney gibi faktörlerinin birbirlerinden farklı olmasından kaynaklanmaktadır.

\section{Drog herba verimi $\left(\mathrm{kg} \mathrm{ha}^{-1}\right)$}

Drog herba verimi 1. yıl $528-635 \mathrm{~kg} \mathrm{ha}^{-1}$ arasında değişmiştir. Humik asit uygulamaları arasında istatistiki bir fark görülmemektedir (Tablo 3). Uygulanan gübre dozları ise elde edilen drog herba verimini olumlu yönde etkilemiştir. $30 \mathrm{~kg} \mathrm{ha}^{-1}$ azot uygulanan parsellerden 663 $\mathrm{kg} \mathrm{ha}^{-1}$ drog herba verimi elde edilmiştir. Humik asit ve gübre uygulamalarına ilişkin interaksiyon ortalamalarında ise en yüksek verim $802 \mathrm{~kg} \mathrm{ha}^{-1}$ ile humik asit uygulanmamış ve $30 \mathrm{~kg} \mathrm{ha}^{-1} \mathrm{da}$ azot uygulanan parsellerden elde edilmiştir. 2. yıl sonuçları incelendiğinde ise humik asit uygulamasıyla, gübre uygulamalarının verim üzerinde etkili olduğu görülmüştür. Buna göre humik asit uygulaması yapılan parsellerde $4760 \mathrm{~kg} \mathrm{ha}^{-1}$ verim elde edilirken, humik asit uygulanmayan parsellerde bu değer (3 $240 \mathrm{~kg} \mathrm{ha}^{-1}$ ) daha düşük kalmıştır. Gübre dozları bakımından ise en yüksek verim istatistiki olarak 30 ve $60 \mathrm{~kg} \mathrm{ha}^{-1}$ azot gübrelemesi yapılan parsellerden elde edilmiştir. En yüksek $4190 \mathrm{~kg}$ $\mathrm{ha}^{-1}$ drog herba verimi $60 \mathrm{~kg} \mathrm{ha}^{-1}$ uygulamasından elde edilirken; bu değer en düşük kontrol uygulamasında (3 $760 \mathrm{~kg} \mathrm{ha}^{-1}$ ) görülmüştür. Özyazıcı ve Kevseroğlu (2019) yaptıkları çalışmalarında drog herba veriminin denemenin ilk yılında ortalama $334 \mathrm{~kg} \mathrm{da}^{-1}$, ikinci yılında ise $1252.9 \mathrm{~kg} \mathrm{da}^{-1}$ olduğunu tespit etmişlerdir. Bu çalışmada elde edilen değerler Özyazıcı ve Kevseroğlu (2019)'a göre düşük olmuştur. Ancak Sönmez ve Okkaoğlu (2019); Arabacı ve Bayram (2005); Ceylan ve ark. (1994); Ceylan ve ark. (1990) gibi araştırıcıların sonuçlarıyla paralellik göstermektedir. Özetle bu çalışmadan elde edilen bulgular ışığında Taze herba verimine bağlı olarak, drog herba verimi ve drog çiçek verimi değerlerinin humik asit uygulamasından olumlu yönde etkilendiği görülmektedir (Tablo 3). Gübre uygulamalarının ise ölçümü yapılan her üç karakterde sadece 1. yılda etkili olduğu da belirlenmiştir (Tablo 3). Burada dikimleri yapılan bitkilerin ilk yıl gübreden kaynaklı olumlu gelişme göstermesi, sonraki yılda ise humik asidin bitkilerin topraktan faydalanma imkânını geliştirmesi yönündeki olumlu etkisi bu sonuçları ortaya çıkarmıştır.

\section{Drog çiçek verimi $\left(\mathrm{kg} \mathrm{ha}^{-1}\right)$}

Drog çiçek verimi 1. yıl humik asit uygulamaları, gübre uygulamaları ve humik asit $\mathrm{x}$ azot dozu interaksiyonları ortalama değerleri arasındaki farkların istatistiki olarak önemli olduğu görülmektedir (Tablo 3 ). Humik asit uygulamaları bakımından en yüksek kuru çiçek verimi $343,4 \mathrm{~kg} \mathrm{ha}^{-1}$ ile humik asit uygulanan parsellerden elde edilirken, en düşük $274,4 \mathrm{~kg} \mathrm{ha}^{-1}$ ile humik uygulanmayan parsellerden elde edilmiştir. Gübre dozu bakımında da en yüksek kuru çiçek verimi $60 \mathrm{~kg} \mathrm{ha}^{-1}$ azot uygulaması 
yapılan parsellerden (341,9 $\mathrm{kg} \mathrm{ha}^{-1}$ ) elde edilirken, en düşük kontrol uygulamasından (261.8 $\mathrm{kg} \mathrm{ha}^{-1}$ ) elde edilmiştir. Humik asit $\mathrm{x}$ gübre dozu interaksiyonu açısından en yüksek verim $401.9 \mathrm{~kg} \mathrm{ha}^{-1}$ ile humik asit uygulanmış ve $60 \mathrm{~kg} \mathrm{ha}^{-1}$ azot verilmiş parsellerden elde edilmiştir. 2. yıl sonuçları incelendiğinde ise sadece humik asit uygulamalarının verim üzerinde etkili olduğu görülmüştür. Humik asit uygulaması yapılan parsellerde $3101 \mathrm{~kg} \mathrm{ha}^{-1}$ verim elde edilirken, humik asit uygulanmayan parsellerde bu değer $1426 \mathrm{~kg} \mathrm{ha}^{-1}$ olarak gerçekleşmiştir. Gübre dozları bakımından istatistiki olarak bir fark belirlenmemiştir. Drog çiçek verimleri 2 151 - $2458 \mathrm{~kg} \mathrm{ha}^{-1}$ arasında değişme göstermiştir.

Tablo 3. Drog herba verimi ve drog çiçek verimi $\left(\mathrm{kg} \mathrm{ha}^{-1}\right)$ karakterlerine ait ortalama değerler ve farkları

Table 3. Average values and differences of drug herb yield and drug flower yield $\left(\mathrm{kg} \mathrm{h}^{-1}\right)$ characters

\begin{tabular}{|c|c|c|c|c|c|c|}
\hline \multirow[t]{2}{*}{ Ölçülen Karakterler } & \multirow{2}{*}{$\begin{array}{l}\text { Yetiştirme } \\
\text { Yılı }\end{array}$} & \multirow[t]{2}{*}{ Humik Asit Uygulaması } & \multicolumn{3}{|c|}{ Azotlu Gübre Uygulaması } & \multirow[b]{2}{*}{ Ortalama } \\
\hline & & & Kontrol & $30 \mathrm{~kg} \mathrm{ha}^{-1}$ & $60 \mathrm{~kg} \mathrm{ha}^{-1}$ & \\
\hline \multirow{6}{*}{$\begin{array}{l}\text { Drog Herba Verimi } \\
\qquad\left(\mathrm{kg} \mathrm{ha}^{-1}\right)\end{array}$} & \multirow{3}{*}{1 yıl (2019) } & Humik Asit Uygulamasız & 519 bc & $802 \mathrm{a}$ & 584 bc & 635 \\
\hline & & Humik Asit Uygulamalı & $444 \mathrm{c}$ & 524 bc & $615 \mathrm{~b}$ & 528 \\
\hline & & Ortalama & $482 \mathrm{~B}$ & $663 \mathrm{~A}$ & $600 \mathrm{AB}$ & \\
\hline & \multirow{3}{*}{ 2.yıl (2020) } & Humik Asit Uygulamasız & 3040 & 3360 & 3330 & $3240 \mathrm{~b}$ \\
\hline & & Humik Asit Uygulamalı & 4480 & 4750 & 5060 & $4760 \mathrm{a}$ \\
\hline & & Ortalama & $3760 \mathrm{~B}$ & $4050 \mathrm{AB}$ & $4190 \mathrm{~A}$ & \\
\hline \multicolumn{7}{|c|}{$\begin{array}{l}\text { Drog herba verimi için: 1. yıl: humik asit uygulaması: ÖD; gübre dozu ve humik asit x gübre dozu interaksiyonu: 0,01 önemli; } \\
\text { 2. yıl ise humik asit uygulaması ve gübre dozu: } 0,01 \text { önemli, humik asit x gübre dozu interaksiyonu ise önemli değil (ÖD); } \\
\text { 1.yıl için CV: \% 9.84; 2.yıl için CV:\% 2.87. }\end{array}$} \\
\hline \multirow{6}{*}{$\begin{array}{l}\text { Drog Çiçek Verimi } \\
\qquad\left(\mathrm{kg} \mathrm{ha}^{-1}\right)\end{array}$} & \multirow{3}{*}{1 yıl (2019) } & Humik Asit Uygulamasız & $231.6 \mathrm{c}$ & $309.7 \mathrm{~b}$ & $281.9 \mathrm{bc}$ & $274.4 \mathrm{~b}$ \\
\hline & & Humik Asit Uygulamalı & $291.9 \mathrm{~b}$ & $336.6 \mathrm{~b}$ & 401.9 a & $343.4 \mathrm{a}$ \\
\hline & & Ortalama & $261.8 \mathrm{~B}$ & $323.2 \mathrm{~A}$ & $341.9 \mathrm{~A}$ & \\
\hline & \multirow{3}{*}{ 2.yıl (2020) } & Humik Asit Uygulamasız & 1357 & 1311 & 1601 & $1426 \mathrm{~b}$ \\
\hline & & Humik Asit Uygulamalı & 2945 & 3051 & 3303 & $3101 \mathrm{a}$ \\
\hline & & Ortalama & 2151 & 2181 & 2458 & \\
\hline
\end{tabular}

Arabacı ve Bayram (2005), yaptıkları çalışmalarında; 2002 yılında $134 \mathrm{~kg} \mathrm{da}^{-1}, 2003$ yılında $216 \mathrm{~kg} \mathrm{da}^{-1}, 2004$ yılında ise $443 \mathrm{~kg} \mathrm{da}^{-1}$ drog çiçek verimi elde ettiklerini belirtmişlerdir. Ceylan ve ark. (1994), yaptıkları çalışmasında; lavanta bitkisinde drog çiçek veriminin 234 $\mathrm{kg} \mathrm{da}^{-1}$ arasında değiştiğini bildirmişlerdir. Sönmez ve Okkaoğlu (2019) ise bu değerin $224.56 \mathrm{~kg} \mathrm{da}^{-1}$ olduğunu, Karık ve ark (2017) ise 32.78-58.37 kg da-1 arasında değiştiğini belirtmişlerdir. Ceylan ve ark. (1990), lavanta bitkisinde drog çiçek veriminin İzmir-Bornova ekolojik koşullarında 164-466 kg da-1 arasında olduğunu tespit etmişlerdir. Özyazıcı ve Kevseroğlu (2019) drog çiçek veriminin çalışmalarının ilk yılında ortalama $184,5 \mathrm{~kg} \mathrm{da}^{-}$ 1 , ikinci yllında ise $744,2 \mathrm{~kg} \mathrm{da}^{-1}$ olduğunu tespit etmişlerdir. Atalay (2008), drog çiçek veriminin 64,12$113,47 \mathrm{~kg} \mathrm{da}^{-1}$ arasında değiştiğini bildirmiştir. Sınmaz (2001) ise bu değerlerin Çukurova koşullarında 51.96$125.0 \mathrm{~kg} \mathrm{da}^{-1}$ arasında değiştiği belirtmişlerdir. Bu çalışmada bulunan sonuçlar ile paralellik göstermektedir.

\section{Uçucu yağ oranı (\%)}

Uçucu yağ oranı bakımından 1.yıl ve 2. yıl sonuçlarına göre değerlendirilen tüm faktörlere ait ortalama değerler arasındaki farkların istatistiki olarak önemli olmadığı belirlenmemiştir (Tablo 4). Buna göre uçucu yağ oranı 1. yıl humik asit uygulaması yapılan ve yapılmayan parsellerde \%3.98-3.89 arasında, uygulanan azot dozları bakımından ise \%3.83-4.02 arasında değişmiştir. 2. yılda da humik asit uygulaması yapılan ve yapılmayan parsellerde \%3.97-3.87arasında, uygulanan azot dozları bakımından ise \%3.86-3.99 arasında değişmiştir. Bu sonuçlara göre yapılan uygulamaların uçucu yağ oranında etkili olmadığı görülmektedir(Tablo 4). Atalay (2008), Konya ekolojik koşullarında lavanta (L. angustifolia Mill.) bitkisinde farklı dozlarda uyguladığı azotlu gübrelemede uçucu yağ oranının \% 2.1-2.6 arasında değiştiğini ifade etmiştir. Ceylan ve ark (1988) lavantada uçucu yağ içeriğinin \% 1.26-3.14 arasında değiştiği; Renaud ve ark (2001). Çiçeklerden elde edilen uçucu yağın lavantada \% 2.8-5.0 arasında olduğunu, lavandin (L. intermedia Emeric ex Loisel) örneklerinde ise \% 7.1-9.9 olduğu belirlenmiştir. Arabacı ve Bayram (2005) ise uçucu yağın \% 1.54-2.34 arasında değiştiğini 
bildirmişlerdir. Yıldııı ve ark (2019), Uşak ili ekolojik koşullarında Lavanta (L. angustifolia Mill) bitkisinde diurnal ve gece-gündüz varyabiliteye göre uçucu yağ oranının ve bileşenlerinin ne şekilde değiştiğini belirlemek üzere yaptıkları çalışmalarında uçucu yağ oranının (\% 6.73-10.27) arasında değiştiğini tespit etmişlerdir. İzmirli (2018), Uşak ili ekolojik koşullarında yetiştirilmiş bulunan Lavanta (L. angustifolia Mill.) bitkileri üzerinde çiçeklenme döneminde; uygulanan farklı $\mathrm{GA}_{3}$ dozlarının lavanta uçucu yağı ve bileşenleri üzerine etkilerini araştırmıştır. En uygun hasat zamanının belirlemek üzere yaptığı çalışmada, drog çiçek numunelerindeki uçucu yağ oranlarının \% 6.2 - 8.2 arasında değiştiğini belirlemiştir. Baydar (2007) Lavandin çeşidinin taze saplı çiçeklerinde uçucu yağ oranını \% 1.01.5 olduğunu belirtmiştir. Kara ve Baydar (2011) yaptıkları bir çalışmasında bu oranın \% 2.24-2.35 arasında değiştiğini, Kara ve Baydar (2012), ise lavandin çeşitlerinde bu oranın \% 0.90-1.25 olduğunu belirtmiştir. Baytop (1999) lavanta çeşidinde ise \% 0.5-1.0 arasında değiştiğini tespit etmiştir. Bu araştırıcıların elde ettikleri sonuçlar taze herba numunelerindeki uçucu yağ miktarlarıdır. Bu çalışmada elde edilen değerler ise kuru drog çiçek örneklerindeki uçucu yağ miktarlarını göstermektedir. Bu yüzden bu değerler diğer araştırıcıların elde ettiği sonuçlardan daha yüksektir.

\section{Uçucu yağ verimi $\left(L h^{-1}\right)$}

Uçucu yağ verimi denemede elde edilen drog çiçek verimine paralel olarak yapılan uygulamalara göre değişiklik göstermiştir (Tablo 4).

Tablo 4. Uçucu yağ oranı (\%) ve Uçucu yağ verimi ( $\mathrm{L} \mathrm{ha}^{-1}$ ) karakterlerine ait ortalama değerler ve farkları Table 4. Average values and differences of essential oil ratio (\%) and essential oil yield ( $\left.\mathrm{L} \mathrm{ha}^{-1}\right)$ characters

\begin{tabular}{|c|c|c|c|c|c|c|}
\hline \multirow{2}{*}{$\begin{array}{c}\text { Ölçülen } \\
\text { Karakterler }\end{array}$} & \multirow{2}{*}{$\begin{array}{c}\text { Yetiştirme } \\
\text { Yılı }\end{array}$} & \multirow{2}{*}{ Humik Asit Uygulaması } & \multicolumn{3}{|c|}{ Azotlu Gübre Uygulaması } & \multirow[b]{2}{*}{ Ortalama } \\
\hline & & & Kontrol & $30 \mathrm{~kg} \mathrm{ha}^{-1}$ & $60 \mathrm{~kg} \mathrm{ha}^{-1}$ & \\
\hline \multirow{6}{*}{$\begin{array}{l}\text { Uçucu Yağ } \\
\text { Oranı (\%) }\end{array}$} & \multirow[t]{3}{*}{1 yıl (2019) } & Humik Asit Uygulamasız & 3.83 & 3.97 & 3.83 & 3.89 \\
\hline & & Humik Asit Uygulamalı & 3.83 & 4.07 & 4.05 & 3.98 \\
\hline & & Ortalama & 3.83 & 4.02 & 3.95 & \\
\hline & \multirow[t]{3}{*}{ 2.yll (2020) } & Humik Asit Uygulamasız & 3.85 & 3.92 & 3.83 & 3.87 \\
\hline & & Humik Asit Uygulamalı & 3.86 & 4.05 & 3.99 & 3.97 \\
\hline & & Ortalama & 3.86 & 3.99 & 3.91 & \\
\hline
\end{tabular}

Uçucu yağ oranı için 1. yıl: humik asit uygulaması, gübre dozu ve humik asit x gübre dozu interaksiyonu: ÖD;

2. yılda da humik asit uygulaması, gübre dozu ve humik asit $x$ gübre dozu interaksiyonu: ÖD;

1.yıl için CV: \% 3.47; 2.yıl CV:\% 3.3.

\begin{tabular}{|c|c|c|c|c|c|c|}
\hline \multirow{6}{*}{$\begin{array}{c}\text { Uçucu Yağ } \\
\text { Verimi } \\
\left(\text { L ha }^{-1}\right)\end{array}$} & \multirow{3}{*}{1 yıl (2019) } & Humik Asit Uygulamasız & $17.8 \mathrm{~d}$ & $24.6 \mathrm{bc}$ & $21.8 \mathrm{c}$ & $21.4 \mathrm{~b}$ \\
\hline & & Humik Asit Uygulamalı & $22.4 \mathrm{c}$ & $27.3 \mathrm{~b}$ & $32.3 \mathrm{a}$ & $27.7 a$ \\
\hline & & Ortalama & $20.1 B$ & $26.0 \mathrm{~A}$ & $27.1 \mathrm{~A}$ & \\
\hline & \multirow{3}{*}{ 2.yıl (2020) } & Humik Asit Uygulamasız & $52.3 \mathrm{~b}$ & $51.4 \mathrm{~b}$ & $61.7 \mathrm{~b}$ & $55.1 \mathrm{~b}$ \\
\hline & & Humik Asit Uygulamalı & $113.6 \mathrm{a}$ & $123.5 \mathrm{a}$ & $132.0 \mathrm{a}$ & $123.0 \mathrm{a}$ \\
\hline & & Ortalama & 82.9 & 87.5 & 96.9 & \\
\hline
\end{tabular}

Uçucu yağ verimi için 1. yıl: humik asit uygulaması: 0,05 ve gübre dozu: 0,01 önemli; humik asit $\mathrm{x}$ gübre dozu interaksiyonu:0,05

2. yıl: humik asit uygulaması: 0,01 önemli, gübre dozu:0,05 ve humik asit x gübre dozu interaksiyonu: 0,05;

1.yıl için CV: \% 7.31; 2.yıl CV:\% 6.42.

1. yıl tüm uygulamalar ve bu uygulamaların interaksiyonuna ait ortalama değerler arasındaki farkların istatistiki olarak önemli olduğu belirlenmiştir. Humik asit uygulaması yapılan parsellerde $27.7 \mathrm{~L}^{\text {ha }}{ }^{-1}$ uçucu yağ verimi elde edilirken humik asit uygulanmayan parsellerde ise bu değer $21.4 \mathrm{~L} \mathrm{ha}^{-1}$ olmuştur. Azot dozları bakımından en yüksek uçucu yağ verimi $27.1 \mathrm{~L} \mathrm{ha}^{-}$ 1 ile $60 \mathrm{~kg} \mathrm{ha}^{-1}$ azot uygulanan parsellerden elde edilmiştir. Oysa bu değer en düşük $20.1 \mathrm{~L} \mathrm{ha}^{-1}$ ile kontrol parsellerinden elde edilmiştir. İnteraksiyonlar bakımından değerler incelendiğinde en yüksek uçucu yağ veriminin $32.3 \mathrm{~L} \mathrm{ha}^{-1}$ ile humik asitli, $60 \mathrm{~kg} \mathrm{ha}^{-1}$ azot uygulaması yapılan parsellerden elde edildiği; en düşük ise humik asit uygulaması yapılmamış kontrol parsellerinden (17.8 $\mathrm{L} \mathrm{ha}^{-1}$ ) elde edilmiştir (Tablo 4). İkinci yılda ise humik asit uygulamalarına ait ortalama değerler arasındaki fark $p=<0.01$ önemli bulunmuştur. Buna göre humik asit uygulaması yapılan parsellerden 123.0 L ha ${ }^{-1}$ uçucu yağ elde edilirken; humik asit uygulanmamış parsellerde $55.1 \mathrm{~L} \mathrm{ha}^{-1}$ uçucu yağ elde edilmiştir. Azot dozlarına ait ortalama değerler arasındaki farklar önemli değildir. En yüksek uçucu yağ 
verimi $60 \mathrm{~kg} \mathrm{ha}^{-1}$ azot uygulanan parsellerden $(96.9 \mathrm{~L}$ ha $\left.{ }^{1}\right)$ elde edilmiştir. Humik asit uygulaması $x$ azot uygulaması interaksiyonu $\mathrm{P}=<0,05$ önemli bulunmuştur. En yüksek uçucu yağ verimi $132 \mathrm{~L} \mathrm{ha}^{-1}$ ile humik asit uygulanan ve $60 \mathrm{~kg} \mathrm{ha}^{-1}$ azot verilen parsellerden elde edilmiştir. En düşük ise $51.4 \mathrm{~L}$ ha-1 ile humik asit uygulanmamış ve $30 \mathrm{~kg} \mathrm{ha}^{-1}$ azot verilmiş parsellerden elde edilmiştir. İkinci yılda uçucu yağ verimindeki bu artış, taze ve drog çiçek verimindeki artıştan kaynaklanmıştır.

Özyazıcı ve Kevseroğlu (2019) tam çiçeklenme döneminde lavanta bitkisinden $5.48 \mathrm{~L} \mathrm{da}^{-1}$ uçucu yağ verimi elde etmişlerdir. Araştırmanın ilk yılında ortalama $0.72 \mathrm{~L} \mathrm{da}^{-1}$, ikinci yılında ise $4.15 \mathrm{~L} \mathrm{da}^{-1}$ uçucu yağ verimi elde edilmiştir. Karık ve. Ark. (2017), Lavanta bitkisinde yaptıkları çalışmalarında uçucu yağ veriminin $0,44-1,93 \mathrm{~L}$ $\mathrm{da}^{-1}$ arasında değiştiğini bildirmişlerdir. Sönmez ve Okkaoğlu (2019) ise L. angustifolia bitkisinde uçucu yağ verimlerinin 4.94-13.69 $\mathrm{L} \mathrm{da}^{-1}$ arasında değiştiğini bildirmişlerdir. Bu çalışmada elde edilen sonuçlar diğer araştırıcıların sonuçlarıyla uyumludur.

\section{Çiçek başağı sayısı (adet parsel ${ }^{-1}$ )}

Denemede yapılan uygulamaların Lavanta bitkisinde çiçek başağı sayısı ne şekilde etkilediğine ilişkin sonuçlar Tablo 5'de sunulmuştur. Buna göre 1. yıl azot uygulamaları ve humik asit uygulaması $\mathrm{x}$ azot dozu interaksiyonu ortalama değerlerine ait farklar istatistiki olarak önemli bulunmuştur. Humik asit uygulamaları arasındaki farklar ise önemli değildir. Azot uygulamaları bakımından, en yüksek çiçek başağı sayısı 610 adet parsel $^{-1}$ ile $60 \mathrm{~kg} \mathrm{ha}^{-1}$ azot uygulaması yapılan parsellerden, en düşük ise kontrol parsellerinden (447.7 adet parsel $^{-1}$ ) elde edilmiştir. Humik asit uygulaması $x$ azot dozu interaksiyonu bakımından ise en yüksek değer humik asit uygulanmış $60 \mathrm{~kg} \mathrm{ha}^{-1}$ parsellerden (673 adet parse $\mathrm{l}^{-1}$ ), en düşük ile humik asit uygulanmamış kontrol parsellinden (419.3 adet parsel-1 ${ }^{-1}$ ) elde edilmiştir. ikinci yıl sonuçları incelendiğinde ise sadece humik asit uygulamaları arasındaki farkların istatistiki olarak önemli olduğu görülmektedir. Humik asit uygulanan parsellerde 3775.3 (adet parsel $^{-1}$ ) çiçek başağı elde edilirken; humik asit uygulanmayan parsellerde 2626 (adet parsel $^{-1}$ ) çiçek başağı elde edilmiştir (Tablo 5).

Tablo 5. Çiçek Başağı sayısı (adet parsel ${ }^{-1}$ ) ve Çiçek Başağı Uzunluğu $(\mathrm{cm})$ karakterlerine ait ortalama değerler ve farkları Table 5. Average values and differences of the characters of flower spike (numbers plot ${ }^{-1}$ ) and flower spike length (cm)

\begin{tabular}{|c|c|c|c|c|c|c|}
\hline \multirow[t]{2}{*}{ Ölçülen Karakterler } & \multirow{2}{*}{$\begin{array}{c}\text { Yetiştirme } \\
\text { Yılı }\end{array}$} & \multirow[t]{2}{*}{ Humik Asit Uygulaması } & \multicolumn{3}{|c|}{ Azotlu Gübre Uygulaması } & \multirow[b]{2}{*}{ Ortalama } \\
\hline & & & Kontrol & $30 \mathrm{~kg} \mathrm{ha}^{-1}$ & $60 \mathrm{~kg} \mathrm{ha}^{-1}$ & \\
\hline \multirow{6}{*}{$\begin{array}{l}\text { Çiçek başağı sayısı } \\
\text { (adet parsel }^{-1} \text { ) }\end{array}$} & 1 yıl (2019) & Humik Asit Uygulamasız & $419.3 \mathrm{c}$ & 663.7 a & $547 \mathrm{~b}$ & 543.3 \\
\hline & & Humik Asit Uygulamalı & $476.0 \mathrm{bc}$ & $546.7 \mathrm{~b}$ & $673 a$ & 565.2 \\
\hline & & Ortalama & 447.7 B & $605.2 \mathrm{~A}$ & $610 \mathrm{~A}$ & \\
\hline & 2.yıl (2020) & Humik Asit Uygulamasız & 2380 & 2876 & 2622 & 2626 \\
\hline & & Humik Asit Uygulamalı & 3636.7 & 3653 & 4036.3 & 3775.3 a \\
\hline & & Ortalama & 3008.4 & 3264.5 & 3329.2 & \\
\hline
\end{tabular}

Çiçek başağı sayısı için: 1. yıl: humik asit uygulaması ÖD; gübre dozu ve humik asit x gübre dozu interaksiyonu: 0,01 önemli;

2. yıl ise humik asit uygulaması 0,01 önemli, gübre dozu ve humik asit x gübre dozu interaksiyonu: ÖD;

1.yıl için CV: \% 6.42; 2.yıl için CV:\% 13.86.

\begin{tabular}{|c|c|c|c|c|c|c|}
\hline \multirow{4}{*}{$\begin{array}{c}\text { Çiçek Başağı } \\
\text { Uzunluğu } \\
\text { (cm) }\end{array}$} & \multirow{3}{*}{1 yıl (2019) } & Humik Asit Uygulamasız & $14.13 \mathrm{a}$ & $13.30 \mathrm{abc}$ & $12.63 \mathrm{bc}$ & 13.35 \\
\hline & & Humik Asit Uygulamalı & $12.27 \mathrm{c}$ & $13.60 \mathrm{ab}$ & $12.17 \mathrm{c}$ & 12.68 \\
\hline & & Ortalama & 13.17 & 13.45 & 12.40 & \\
\hline & \multirow{3}{*}{ 2.yıl (2020) } & Humik Asit Uygulamasız & 13.67 & 13.67 & 11.67 & 13.00 \\
\hline & & Humik Asit Uygulamalı & 12.67 & 13.67 & 13.00 & 13.11 \\
\hline & & Ortalama & 13.17 & 13.67 & 12.34 & \\
\hline
\end{tabular}

Çiçek başağı uzunluğu için: 1. yıl: humik asit uygulaması ve gübre dozu ÖD; humik asit x gübre dozu interaksiyonu 0,01 önemli;

2. yıl ise humik asit uygulaması, gübre dozu ve humik asit x gübre dozu: ÖD;

1.yıl için CV: \% 3.13; 2 .yıl için CV:\% 7.55

\section{Çiçek başağı uzunluğu (cm)}

Uygulamaların çiçek başağı uzunluğu üzerine ne şekilde etkili olduğu Tablo 5'de görülmektedir. Buna göre 1. yıl humik asit uygulaması $\mathrm{x}$ azot dozu interaksiyonu ortalama değerlerine ait farklar istatistiki olarak önemli bulunmuştur. Humik asit uygulamaları ve azot dozları arasındaki farklar ise önemli değildir. Humik asit uygulaması $x$ azot dozu interaksiyonu bakımından en düşük değer humik asit uygulanan ve $60 \mathrm{~kg} \mathrm{ha}^{-1}$ azot verilmiş parsellerden $12.17 \mathrm{~cm}$ elde edilmiştir. En yüksek ise $14.13 \mathrm{~cm}$ ile humik asit uygulanmamış kontrol parsellinden elde edilmiştir. Bu sonuçlar yukarıda bahsedilen çiçek başağı sayısı değerlerine göre ters gibi görünse de artan çiçek başağı sayısında başak 
uzunluğunun da kısaldığını söylemek doğru olacaktır. Bitkide başak sayısı az olduğunda başağın daha uzun olduğu belirlenmiştir. İkinci yıl sonuçları incelendiğinde başak uzunluğu bakımından uygulamaların bir etkisi söz konusu değildir (Tablo 5).

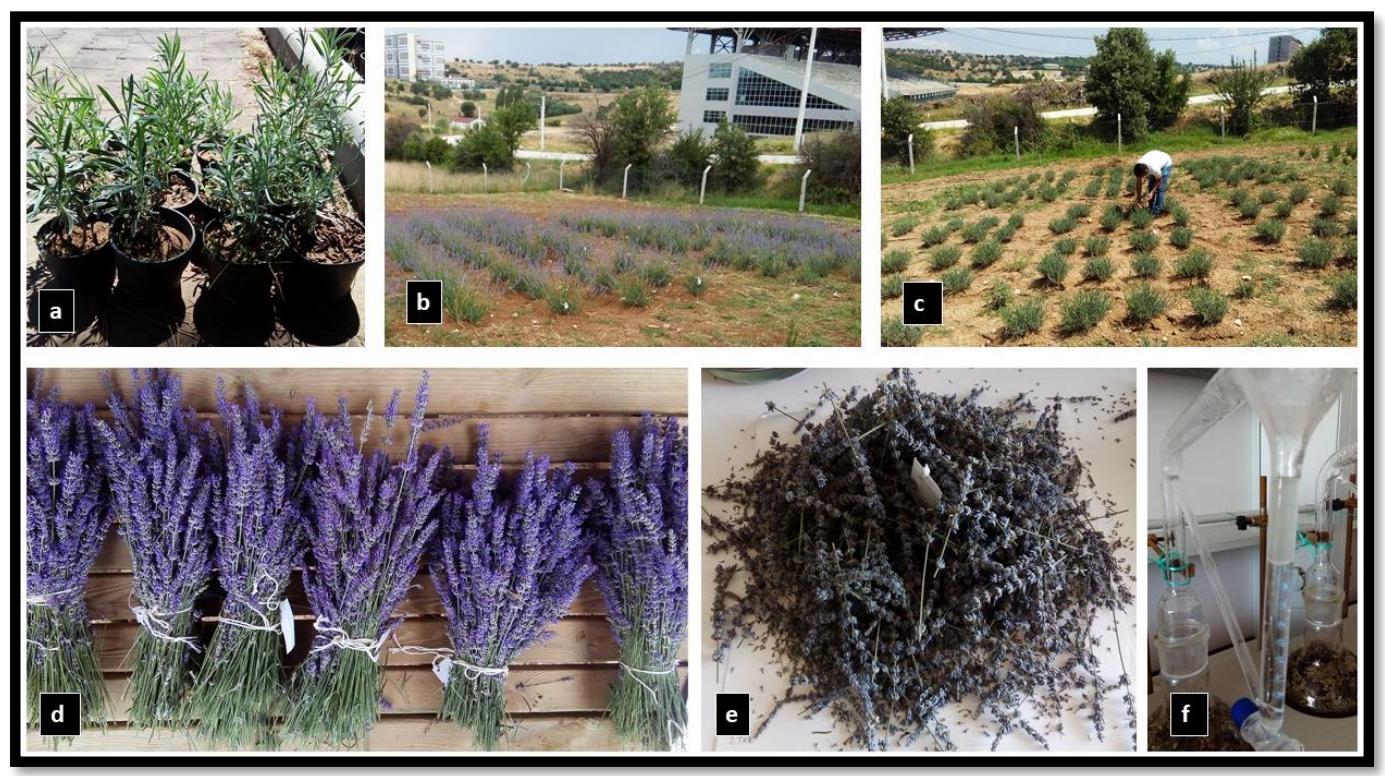

Şekil 1: a) denemede dikimi yapılan bitkiler, b-c) denemenin 1. yılına (2019) ait görüntüler ve hasat dönemi, d-e) hasad edilen taze herba ve drog herba, f) uçucu yağın elde edilmesi

Figure 1: a b-c) General view and harvest period of the first year of the study (2019), d-e) fresh herbs and drug herbs harvested, f) obtaining essential oil

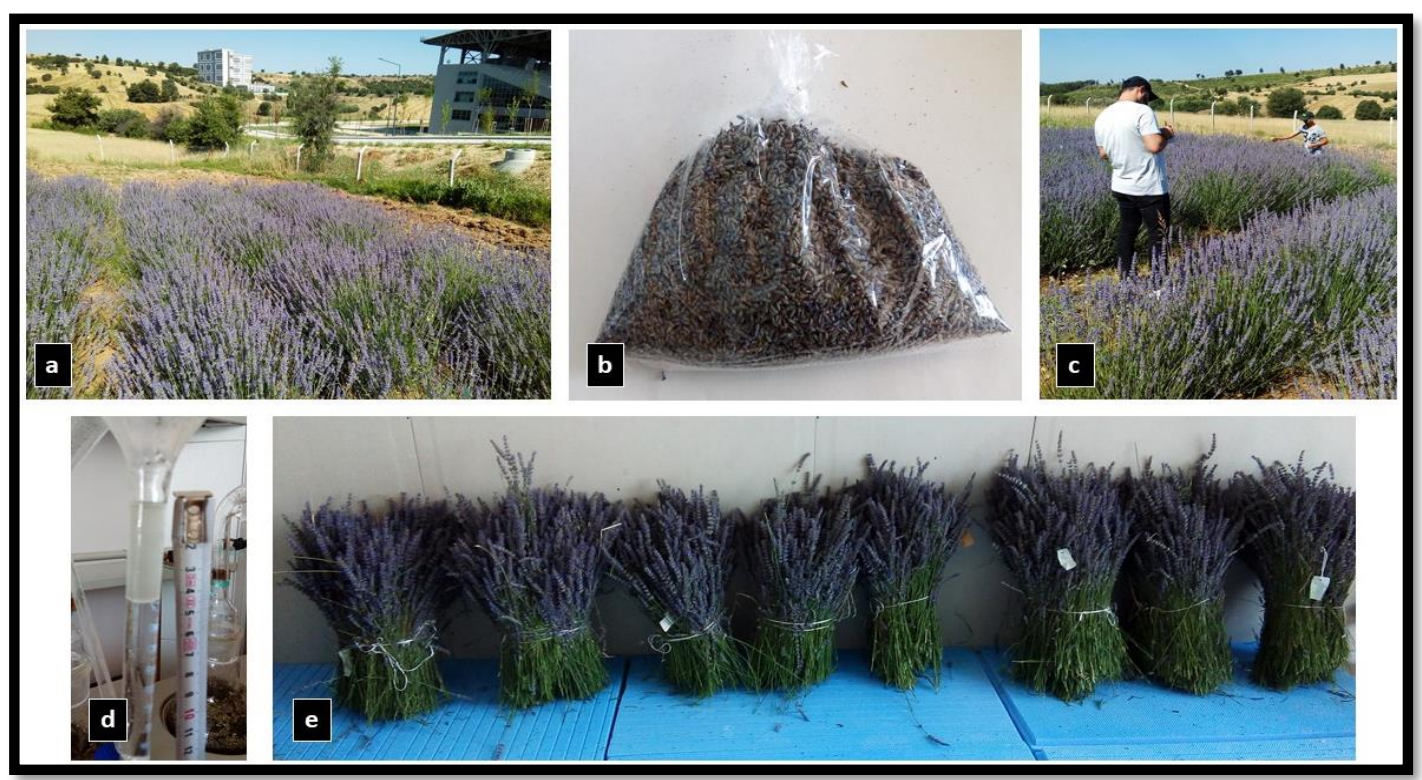

Şekil 2: a-c) denemenin 2. yılına (2020) ait görüntüler, b-e) drog çiçek, hasad edilen taze herba, d) uçucu yağın elde edilmesi.

Figure 2: $a-c$ ) Views of the 2nd year (2020) of the study, b-e) harvested drug flowers and fresh herbs, d)obtaining essential oil.

Atalay (2008), yaptığı çalışmasında çiçek boyu uzunluğunun 17.64-20.57 cm arasında değiştiğini belirlemiştir. Ceylan (1996), çiçek başağı uzunluğunun 16-20 cm arasında değiştiğini bildirmiştir. Bu çalışmada elde edilen sonuçlar diğer araştırııların buldukları sonuçların alt sınııında yer almaktadır.

Yukarıdaki sonuçlara göre humik asit uygulamasının lavanta (L. angustifolia) bitkisinde bazı bitkisel 
özelliklerin yanı sıra taze ve drog herba veriminin arttırılmasında da etkili olduğu görülmüştür. Çalışmada uçucu yağ oranı ve çiçek başağı uzunluğu üzerinde humik asit uygulamasının net bir etkisi olmadığı da belirlenmiştir. Daha önce de belirtildiği gibi lavantada humik asit uygulamasına yönelik Türkiye'de yapılmış bir çalışma bulunmamaktadır. Bu yüzden başka bitkilerde yapılmış diğer araştırma sonuçlarıyla değerlendirilmeye çalışıldığında; diğer araştırıcıların humik asidin verimi arttırdığına yönelik tespit ettikleri bulgularla uyumludur. Mısır yetiştiriciliğinde; organik maddesi az olan toprağa humik asit uygulaması yapıldığında; bitkideki kuru madde miktarını artırdığı (Lee ve Bartlett, 1976) belirlenmiştir. Yine humik asit uygulamasının mısırda fosfor içeriğini ve topraktaki yarayışlı fosfor miktarını çoğalttığı ifade edilmiş̧ir (Erdal ve ark., 2000). Diğer bir çalışmada da, saksıda yetiştirilen mısır (Zea mays L.) fidelerine $0,50,100,150,200,250$ ve $300 \mathrm{mg} \mathrm{kg}^{-1}$ oranında; humik asitle birlikte $\mathrm{N}, \mathrm{P}$ ve $\mathrm{K}$ uygulanmıştır. Bunun sonucunda 50 ve $100 \mathrm{mg} \mathrm{kg}^{-1}$ eklenen humik asidin, mısır bitkisinin gövdesini sırasıyla \% 20 ve \%23 büyüttüğü tespit edilmiştir (Sharif ve ark. 2002). Bu konularda yürütülen çok sayıdaki araştırmada humikli maddelerin toprakta bitki besin maddelerinin yarayışlılığını arttırdığı, bitkiler tarafından makro ve mikro besin maddelerinin alımını düzenlediği tespit edilmiştir (Karaman ve ark., 2012). Ayçiçeğinde yapılan bir çalışmada da ise humik asit uygulamasının verim ve yağ oranını olumlu yönde etkilediği belirlenmiştir. Bitki gelişme dönemlerine göre yapılacak humik asit dozlarının önemli olduğu; ekimden önce toprağa yapılacak uygulamalarda $18 \mathrm{~g} \mathrm{da}^{-1}$, bitkiler 4-5 yapraklı iken yapılacak uygulamanın $12 \mathrm{~g} \mathrm{da}^{-1}$ ve erken dönemde tabla oluşumu döneminde ise $6 \mathrm{~g} \mathrm{da}^{-1}$ uygulamanın verimini arttırdığı belirlenmiştir (Day ve ark., 2011). Önemli organik madde kaynaklarından birisi olarak humik asidin farklı dozlarının bitkilerde potasyumun alımı üzerine etkisi konusunda yürütülen bir diğer çalışmada $4 \mathrm{~L} \mathrm{da}^{-1}$ humik asit uygulamasında da toprakta en fazla potasyum miktarına ulaşıldığı belirtilmiştir. Bitki gövdesinde $8 \mathrm{~L} \mathrm{da}^{-1}$, bitki kökünde ise $10 \mathrm{~L} \mathrm{da}^{-1}$ humik asit uygulamasının en fazla potasyum oluşumuna neden olduğu belirlenmiştir (Alak ve Müftüoğlu (2014).

\section{SONUÇ ve ÖNERILER}

Elde edilen sonuçlara göre humik asit uygulamasını lavanta bitkisinde özellikle taze herba, drog herba ve drog çiçek verimlerini arttırdığı belirlenmiştir. Humik asit uygulamaları denemede ölçümü yapılan diğer bazı karakterleri de (bitki boyu, uçucu yağ verimi, çiçek başağı sayısı) olumlu etkilemiştir. Tek başına humik asit uygulamalarının, uçucu yağ oranı ve çiçek başağı uzunluğu üzerinde ise bir etkisi olmamıştır. Humik asit uygulamalarının etkisi ise ikinci yıldan itibaren çok daha belirgin görülmüştür. Buna göre humik asit uygulamasının lavanta yetiştiriciliğinde faydalı olacağı sonucuna varılmıştır. Azot uygulamaları ise çiçek başağı sayısı, taze herba, drog herba, drog çiçek ve uçucu yağ verimini olumlu yönde etkilemiştir. Yapılan azot ve humik asit uygulamalarından, her iki yılda da sadece uçucu yağ oranı etkilenmemiştir. Bu çalışmada $30-60 \mathrm{~kg}$ $\mathrm{ha}^{-1}$ azot uygulamasıyla lavantada verim artışı sağlanmıştır.

\section{ÖZET}

Amaç: Bu çalışma, humik asit ve azotlu gübre dozlarının lavanta (L. angustifolia Mill.) bitkisinin bazı bitkisel özelikleri ve verimi üzerine etkisini belirlemek amacıyla yürütülmüştür.

Yöntem ve Bulgular: Deneme; 2019-2020 yıllarında, Uşak Üniversitesi Ziraat Fakültesi Araştırma ve Uygulama alanında yürütülmüştür. Denemede humik asit uygulanmış (100 kg ha-1) ve uygulanmamış (Kontrol) parsellere, 3 farklı dozda (Kontrol, $30 \mathrm{~kg} \mathrm{ha}^{-1}, 60 \mathrm{~kg} \mathrm{ha}^{-1}$ ) azotlu gübreleme yapılmıştır. Deneme tesadüf bloklarında bölünmüş parseller deneme desenine göre 3 tekrarlamalı olarak yürütülmüştür. Ana parselleri humik asit uygulamaları alt parselleri ise azot dozları oluşturmuştur. Çalışmada; bitki boyu $(\mathrm{cm})$, taze herba verimi $\left(\mathrm{kg} \mathrm{ha}^{-1}\right)$, drog herba verimi $\left(\mathrm{kg} \mathrm{ha}^{-1}\right)$, drog çiçek verimi ( $\left.\mathrm{kg} \mathrm{ha}^{-1}\right)$, uçucu yağ oranı (\%), uçucu yağ verimi (L ha ${ }^{-1}$ ) çiçek başağı sayısı (adet parsel ${ }^{-1}$ ) ve çiçek başağı uzunluğuna $(\mathrm{cm})$ ilişkin ölçümler yapılmıştır.

Genel Yorum: Elde edilen sonuçlara göre, denemede 1. yıl, humik asit uygulanan parsellerde drog çiçek verimi $343 \mathrm{~kg} \mathrm{ha}^{-1}$ iken, humik asit uygulanmayan parsellerde $274 \mathrm{~kg} \mathrm{ha}^{-1}$ olmuştur. íkinci yılda ise bu değerler sırasıyla 3101 ile $1426 \mathrm{~kg} \mathrm{ha}^{-1}$ olarak belirlenmiştir. Uçucu yağ verimi ise humik asit uygulanan parsellerde ilk yılda 27,7 $\mathrm{L} \mathrm{ha}^{-1}$, ikinci yılda $123 \mathrm{~L} \mathrm{ha}^{-1}$ olarak belirlenirken, humik asit uygulanmayan parsellerde sırasıyla 21,4 ile 55,1 L ha ${ }^{1}$ olmuştur.

Çalışmanın Önemi ve Etkisi: Humik asit uygulamasının lavanta bitkisinin gelişmesinde olumlu katkısının olduğu ve yapılacak olan azotlu gübreleme miktarının 30-60 kg $\mathrm{ha}^{-1}$ arasında uygun olduğu belirlenmiştir.

Anahtar Kelimeler: Lavanta, leonardit, organik madde, uçucu yağ, gübre.

\section{TEŞEKKÜR}

$\mathrm{Bu}$ çalışma, Uşak Üniversitesi Lisansüstü Eğitim 
Enstitüsü, Tarım Bilimleri Anabilim Dalı'nda yüksek lisans tezi olarak yürütülen bir çalışmasından hazırlanmıştır.

\section{ÇIKAR ÇATIŞMA BEYANI}

Yazar(lar) çalışma konusunda çıkar çatışmasının olmadığını beyan eder.

\section{ARAŞTIRMACILARIN KATKI ORANI BEYANI}

Yazarlar çalışmaya eşit oranda katkı sağlamış olduklarını beyan eder.

\section{KAYNAKLAR}

Akıncı Ş (2011) Humik asitler, bitki büyümesi ve besleyici alımı, Marmara Üniversitesi, Fen Bilimleri Dergisi 23(1): 46-56.

Alak HC, Müftüoğlu NM (2014) Humik asit uygulamalarının alınabilir potasyum üzerine etkisi, ÇOMÜ Ziraat Fakültesi. Dergisi 2(2): 61-66.

Altınbaş Ü, Çengel M, Uysal H, Okur B, Okur N, Kurucu Y, Delibacak S (2004) Toprak Bilimi, Ege Üniversitesi Ziraat Fakültesi Yayınları, İzmir, Türkiye, 557, 175s.

Arabacı O, Bayram E (2005) Aydın ekolojik koşullarında lavanta (Lavandula angustifolia Mill.)'nın bazı agronomik ve kalite özellikleri üzerine bitki sıklığı ve azotlu gübrenin etkisi. ADÜ Ziraat Dergisi 2(2): 13-19.

Atalay AT (2008) Konya ekolojik şartlarında yetiştirilen lavanta (Lavandula angustifolia L.)'da farklı dozlarda uygulanan organik ve inorganik azotlu gübrelerin verim ve kalite özellikleri üzerine etkileri. Yüksek Lisans Tezi, Selçuk Üniversitesi Fen Bilimleri Enstitüsü, Tarla Bitkileri ABD, 46 s, Konya.

Avşaroğlu N (2019). Tarımda Yüzyılın Madeni Leonardit. https://www.leonardit.com.tr/image/catalog/pdf/ 04-tarimda-yüzyilin-madeni-leonardit.pdf (Erişim Tarihi:18 Eylül 2020).

Ay F (2015) Hümik asit ve hümik kaynaklarının jeolojik ve ekonomik önemi, Cumhuriyet Üniversitesi Fen Fakültesi 36(1): 28-51.

Balyemez ÖE (2014) Harran ovası koşullarında farklı lavanta (Lavandula spp.) türlerinin verim ve bazı bitkisel özelliklerinin belirlenmesi, Yüksek Lisans Tezi, Harran Üniversitesi, Fen Bilimleri Enstitüsü, Şanlıurfa.

Baydar H (2007) Tıbbi, Aromatik ve Keyf Bitkileri Bilimi ve Teknolojisi (2. Baskı). Süleyman Demirel Üniversitesi Yayın No: 51. Isparta.

Baytop T (1999) Türkiye'de Bitkiler ile Tedavi (Geçmiste ve Bugün) İlaveli ikinci Baskı, Nobel Tıp Kitabevleri, Istanbul.
Bozkıran S, Giray FH (2014) Isparta'da lavanta üretimi ve pazarlaması XI. Ulusal Tarım Ekonomisi Kongresi 3-5 Eylül 2014, Samsun, ss.1365-1368.

Ceylan A, Vomel A, Kaya N, Celik N, Nigdeli E (1988) An investigation on effects to yield and quality of plant space in lavender (in Turkish). Ege Üniv. Ziraat Fak. Dergisi 25(2): 135-145.

Ceylan A, Kaya N, Bayram E (1990) Sulamadan lavanta (Lavandula officinalis L.) üretimi ve azotlu gübrenin etkisi üzerinde bir araştırma. Ege Üniversitesi Ziraat Fakültesi Dergisi 28(2-3): 163-178.

Ceylan A, Bayram E, Özay N (1994) Bazı parfüm bitkileri üzerine agronomik ve teknolojik araştırmalar. I. Lavandula angustifolia Mill., Tarla Bitkileri Kongresi, 25-29 Nisan, İzmir, ss.137-141.

Ceylan A (1996) Tıbbi Bitkiler II (Uçucu Yağ Bitkileri) Ege Üniversitesi Ziraat Fakültesi Yayın no:481, Bornova İmir. $306 \mathrm{~s}$.

Ceylan A, Bayram E, Özay N (1996) Farklı bitki sıklığı ve azot dozlarının lavanta (Lavandula angustifolia Mill.)'nın bazı agronomik ve teknolojik özelliklere etkisi. Tr. J. of Agriculture and Forestry 20: 567-572.

Day S, Kolsarıcı Ö, Kaya MD (2011) Humik asit uygulama zamanı ve dozlarının ayçiçeğinde (Helianthus annuus) verim, verim öğeleri ve yağ oranına etkisi, Akdeniz Üniversitesi Ziraat Fakültesi Dergisi 24(1): 33-37.

Engin VT, Cöcen, i, İnci U (2012) Türkiye'de Leonardit. SA.Ü. Fen Edebiyat Dergisi 14(1): 435-443.

Erdal i, Bozkurt MA, Çimrin KM, Karaca $S$, Sağlam M (2000) Kireçli bir toprakta yetiştirilen mısır bitkisi ( $Z$. mays L.) gelişimi ve fosfor alımı üzerine humik asit ve fosfor uygulamasının etkisi. Turkish Journal of Agriculture and Forestry 24: 663-668.

İstanbulluoğlu S (2012) Leonardit Nedir? https://www.siamad.com.tr/leonardit-nedir (Erişim Tarihi: 18.Eylül.2020).

Izmirli A (2018) Effect of different gibberellic acid $\left(\mathrm{GA}_{3}\right)$ doses on Lavandula angustifolia Mill. essential oil content and components. Yüksek Lisans Tezi, Uşak Üniversitesi, Fen Bilimleri Enstitüsü, Tarım Bilimleri $A B D, 72 s$.

Kara N, Baydar H (2011) Türkiye'nin lavanta üretim merkezi olan Isparta ilinin Kuyucak yöresi lavantalarının (L.x intermedia Emeric ex Loisel.) uçucu yağ özellikleri. Selçuk Tarım ve Gıda Bilimleri Dergisi 25(4): 41-45.

Kara N, Baydar H (2012) Essential oil contents and composition of lavenders and lavandins cultivated in Turkey. Research on Crops 13(2): 675-681.

Karaman MR, Şahin S, Geboloğlu N, Turan M, Güneş A, Tutar A (2012). Humik asit uygulaması altında farklı 
domates çeşitlerinin (Lycopersicon esculentum L.) demir alım etkinlikleri. Sakarya Üniversitesi, Fen Edebiyat Dergisi 14(1): 301-308.

Karık Ü, Çiçek F, Çınar O (2017) Menemen ekolojik koşullarında lavanta (Lavandula spp.) tür ve çeşitlerinin morfolojik, verim ve kalite özelliklerinin belirlenmesi. Anadolu 27(1): 17-28.

Lee YS, Bartlett RJ (1976) Stimulation of plant growth by humic substances. Soil Sci. Soc. Am. J. 40: 876-879.

Özyazıcı G, Keseroğlu K (2019) Ontogenetik varyabilitenin Labiatae familyasına ait bazı bitkiler (Mentha spicata L., Origanum onites L., Melissa officinalis L., Lavandula angustifolia Mill.)'in verimi üzerine etkileri. Türkiye Tarımsal Araştırmalar Dergisi (Turkısh Journal of Agricultural Research) 6(2): 174185.

Renaud ENC, Charles DJ, Simon JE (2001) Essential oil quantity and composition from 10 cultivars of organically grown lavender and lavandin. J. Essent. Oil Res. 13(4): 269-273.
Sharif M, Khattak RA, Sarir MS (2002) Effect of different levels of lignitic coal derived humic acid on growth of maize plants. Soil Science and Plant Analysis 20: 35673580.

Sınmaz T (2001) Çukurova bölgesi kıraç koşullarında lavanta (Lavandula officinalis Chaix)'nın yetiştirilme olanakları. Doktora Tezi, Çukurova Üniversitesi Fen Bilimleri Enstitüsü, 68s.

Sönmez Ç, Okkaoğlu H (2019) The effect of diurnal variation on some yield and quality characteristics of lavender (Lavandula angustifolia Mill.) under Çukurova ecological conditions. Turkish Journal of Agriculture-Food Science and Technology 7(3): 531535.

Yıldırım MU, Sarıhan EO, Kul H, Khawar KM (2019) Diurnal and nocturnal variability of essential oil content and components of Lavandula angustifolia Mill. (lavender). Mustafa Kemal University Journal of Agricultural Sciences 24(3): 268-278. 